\title{
Endotracheal intubation in intensive care unit: a prospective study of clinical practice and adverse events
}

\author{
SK Pattnaik*, J Nayak, S Choudhary, JP Pati \\ From ESICM LIVES 2015 \\ Berlin, Germany. 3-7 October 2015
}

\section{Introduction}

Intubation in critical care unit patients is a difficult proposition due to multiple limiting factors like full stomach, hemodynamic instability, emergency circumstances, difficult positioning, all leading to increased adverse events during intubation.

\section{Objectives}

To describe the practice of endotracheal intubation in the Intensive care unit of a tertiary care teaching hospital, with particular emphasis on the indication, medications used, time of day, staff seniority, number of attempts required and any adverse events.

\section{Methods}

This was a prospective observational study of intubation practice over a 6 months period from 1st October 2014 to 31st march 2015.

\section{Results}

Out of 250 intubations performed with in the time frame, acute respiratory failure $(54.5 \%)$ was the most common indication followed by trauma. $56.25 \%$ intubations done in odd hours (8AM-8PM) having 63.45\% success rate on first attempt.

Consultants made the successful first attempt at intubation in $84.5 \%$ (95\% CI 794.0-88.5), whereas registrars or senior Resident Medical Officers made the first attempt at intubation in 66.6\% (95\% CI 60.9-71.3).

Complications occurred in $20.10 \%$ cases: desaturation, 7.2\%; hypotension, 6.5\%; aspiration, $3.8 \%$; esophageal intubation, $1.3 \%$; dental injury, $1.2 \%$; and pneumothorax, $0.1 \%$.

\footnotetext{
Apollo Hospitals, Bhubaneswar, India

\section{SpringerOpen ${ }^{\circ}$}

(c) 2015 Pattnaik et al.; This is an Open Access article distributed under the terms of the Creative Commons Attribution License (http:// creativecommons.org/licenses/by/4.0), which permits unrestricted use, distribution, and reproduction in any medium, provided the original work is properly cited.
Fentanyl plus midazolam combination (70\%) was the most common drugs used for intubation. attempts, whereas a stylet in $37.5 \%$ (95\% CI 32.1-43.3).

\section{Conclusions}

Intubation in critical care unit patients is a risky procedure which needs a standard operating guidelines to decrease the adverse events.

Published: 1 October 2015

doi:10.1186/2197-425X-3-S1-A940

Cite this article as: Pattnaik et al.: Endotracheal intubation in intensive care unit: a prospective study of clinical practice and adverse events. Intensive Care Medicine Experimental 2015 3(Suppl 1):A940.

Submit your manuscript to a SpringerOpen ${ }^{\circ}$ journal and benefit from:

- Convenient online submission

- Rigorous peer review

- Immediate publication on acceptance

- Open access: articles freely available online

- High visibility within the field

- Retaining the copyright to your article

Submit your next manuscript at $>$ springeropen.com
A bougie was used in 30.9\% (95\% CI 25.8-36.5) of first 